\title{
ANALISIS PERSEPSI PETANI BAWANG MERAH TERHADAP PROGRAM PENGEMBANGAN BAWANG MERAH DI KABUPATEN KAMPAR
}

\author{
Amalia dan Asgami Putri \\ Amaliamasjkur@unilak.ac.id, Asgami@unilak.ac.id \\ Fakultas Pertanian, Universitas Lancang Kuning, Pekanbaru, Indonesia
}

\begin{abstract}
ABSTRAK
Tujuan dari penelitian ini adalah: menganalisis persepsi petani tanaman bawang merah terhadap program pengembangan tanaman bawang merah.

Metode penelitian yang digunakan adalah metode survei yang diterapkan adalah teknik wawancara dan observasi atau supervisi langsung pada lokasi obyek pengembangan bawang merah. Pengarahan wawancara serta ketepatan pengumpulan data yang dibutuhkan berpedoman pada daftar pertanyaan terstruktur.

Teknik penetapan sampling lokasi/wilayah dilakukan secara purposive didasarkan pada potensi dan daya dukung pengembangan komoditi tersebut. Sedangkan sampel responden diambil dengan metode cluster purvosif sampling untuk mengelompokkan sampel sesuai dengan tujuan penelitian, ditentukan sebayak 100 orang yang diambil dari anggota kelompok tani sebagai pelaku usaha produksi bawang merah. Teknik analisis yang digunakan adalah penelitian Deskriptif (Descriptive Research).

Dari hasil penelitian bahwa persepsi petani yang masuk pada kategori tinggi adalah kriteria Dukungan/keterlibatan masyarakat sebesar 114,10\%, kriteria bantuan saprodi sebesar $123.47 \%$, dan bantuan bibit sebesar $101.10 \%$ artinya rataan persepsi petani bawang merah di Kabupaten Kampar dengan kriteria tersebut lebih dari $100 \%$. Kemudian kriteria persepsi petani yang masuk dalam kategori rendah adalah kejelasan program sebesar 93,27\%, ketepatan sasaran program sebesar $89,74 \%$, pendampingan dan penyuluhan sebesar $86.81 \%$ dan bantuan pembiayaan sebesar $91,49 \%$, kriteria ini dikatakan rendah karena persentase rataan kriteria tersebut kurang dari $100 \%$.
\end{abstract}

Kata Kunci : Program pengembangan, persepsi, bawang merah.

\section{PENDAHULUAN}

Berbagai strategi kebijakan dan program-program pembangunan di Kabupaten Kampar khususnya dibidang Pertanian dan Ketahanan Pangan yang dituangkan didalam Rencana Strategik (Renstra) secara nyata dirancang dengan mempertimbangkan jumlah, kualitas dan sebaran potensi sumberdaya yang dimiliki. Situasi ini semakin penting pada era otonomi daerah dimana pada satu sisi memberikan peluang dan keleluasaan yang cukup besar bagi daerah dalam merancang pelaksanaan pembangunan daerah wilayahnya. Akan tetapi pada sisi

87 Analisis Persepsi Petani Bawang Merah Terhadap Program Pengembangan Bawang Merah Di Kabupaten Kampar 
yang lain merupakan tantangan tersendiri, sebagai akibat daerah harus mampu menumbuh kembangkan kreativitasnya terutama berupa upaya-upaya nyata dalam mempercepat kemajuan pembangunan daerahnya.

Pemerintah Kabupaten Kampar dalam upaya meningkatkan kesejahteraan masyarakatnya melalui subsektor hortikultura telah melakukan pengembangan budi daya bawang merah, dimana budidaya bawang merah belum pernah dikembangkan diKabupaten Kampar, dikarenakan sebagian besar lahan di Kabupaten Kampar adalah lahan gambut.

Terkait produksi bawang merah, Kementerian Pertanian telah melakukan berbagai pengembangan dan penelitian guna memenuhi kebutuhan produksi bawang merah dalam negeri termasuk dalam pengembangan budidaya bawang merah di lahan gambut. Penanaman bawang merah di lahan gambut ini merupakan program terobosan sebagai upaya pengembangan lebih luas pertanaman bawang merah spesifik lahan gambut termasuk pada kondisi di luar musim (curah hujan tinggi). Selain dikarenakan melihat wilayah negeri kita yang memiliki potensi dataran rendah lahan gambut yang luas.

Berdasarkan hasil penemuan IPTEK pengembangan budi daya bawang merah dilahan gambut tersebut Pemerintah Kabupaten Kampar menangkap peluang peningkatan kesejahteraan masyarakatnya melalui terobosan pengembangan budi daya bawang merah di wilayah Kabupaten Kampar. Hingga saat ini, produksi bawang merah di Kabupaten Kampar hanya untuk keperluan dalam wilayah saja. Namun perlahan akan memperluas pasar komoditas ini ke Kabupaten hingga propinsi tetangga. Pemerintah Kabupaten Kampar juga menargetkan akan menjadi sentra tanaman bawang merah di Sumatra pada tahun 2016. Salah satu lahan terbesar terletak di Desa Geringging Kecamatan Kampar Kiri yang memiliki 13 hektar lahan bawang merah.

Menurut Titiek Purbiati (2012), dalam budi daya bawang merah dilahan gambut perlu mengadopsi penelitian-penelitian dan modifikasi sehingga sesuai secara agroekosistemnya yang meliputi pengirisan gambut, pengolahan lahan, pemberian pupuk, pembersihan gulma, meneralkan $\mathrm{pH}$ dan pembuatan bedengan. Penerapan teknologi tentunya memerlukan biaya yang besar, untuk itu pemerintah juga membantu biaya pengembangan dengn APBD senilai Rp.6 Milyar dan 
APBN Rp.3 Milyar, sedangkan kementrian pertanian akan merealisasikan bantuan Rp.2,5 Milyar untuk lahan di Desa Bima, Desa Kampar dan Desa Nganjuk.

Berdasarkan hasil penelitian Yasid, H dkk (2015) bahwa di Desa Sungai Geringging Kecamatan Kampar Kiri Kabupaten Kampar komoditi bawang merah mempunyai potensi komoditi unggulan daerah dengan catatan perlu adanya upaya berkelanjutan dalam perbaikan kendala yang masih dihadapi seperti terkait infrastruktur, teknologi budidaya, dan keterampilan petani yang harus terus ditingkatkan.

Jumlah petani yang membudidayakan tanaman bawang merah secara menyeluruh seharusnya menjadi tolok ukur yang dapat memberikan nilai yang cukup signifikan bagi pendapatan masyarakat, akan tetapi sejalan dengan program pemerintah hingga saat ini belum ada fakta berupa angka-angka yang menjadi pembanding berapa besarnya pendapatan yang diperoleh oleh masyarakat dengan ketersediaan lahan yang ada untuk menghasilkan tanaman bawang merah.

Salah satu yang mempengaruhi keberhasilan suatu program pemerintah adalah persepsi petani sebagai pelaksana program tersebut, apabila persepsi petani baik terhadap program tersebut maka akan menjadi salah satu motivasi bagi petani tersebut untuk berusaha sebaik mungkin agar program tersebut dapat berjalan sehingga dapat meningkatkan kesejahteraan petani tersebut. Dari persepsi petani pemerintah sebagai pembuat program juga isa mengetahui apa saja bagian dari program tersebut yang kurang tepat bila dilihat dari persepsi petani, sehingga akan menjadi bahan evaluasi bagi pemerintah dalam membuat dan menjalankan program yang telah dirancang.

Tujuan penelitian ini adalah menganalisis persepsi petani terhadap program pengembangan bawang merah di Kabupaten Kampar.

\section{METODE PENELITIAN}

Penelitian ini dilaksanakan dari bulan Maret 2016 sampai dengan bulan September 2016. Jenis data yang digunakan dalam penelitian ini adalah Data Primer dan Sekunder.

Metode penelitian yang digunakan adalah metode survei yang diterapkan adalah teknik wawancara dan observasi atau supervisi langsung pada lokasi obyek pengembangan bawang merah. Pengarahan wawancara serta ketepatan 
pengumpulan data yang dibutuhkan berpedoman pada daftar pertanyaan terstruktur.

Teknik penetapan sampling lokasi/wilayah dilakukan secara purposive didasarkan pada potensi dan daya dukung pengembangan komoditi tersebut. Sedangkan sampel responden diambil dengan metode cluster purvosif sampling untuk mengelompokkan sampel sesuai dengan tujuan penelitian, ditentukan sebayak 100 orang yang diambil dari anggota kelompok tani sebagai pelaku usaha produksi bawang merah.

Untuk menguji hasil penelitian digunakan Analisi Kuantitatif Deskriptif (\%). Analisis kuantitatif deskriptif adalah cara menganalisis dengan mendeskrisikan atau menggambarkan data yang telah terkumpul sebagaimana adanya tampa membuat kesimpulan yang berlaku untuk umum atau generalisasi pada penelitian terdapat 100 responden yang meliputi Kejelasan Program, Ketepatan Sasaran Program, Dukungan Masyarakat, Keberhasian Program, Keterlibatan Masyarakat, pendampingan, Kecukupan dana, Program terhadap peningkatan pendapatan. Deskriptif persentase ini diolah dengan cara frekuensi dibagi jumlah responden dikali $100 \%$, seperti dikemukakan Sudjana (2001) adalah sebagai berikut:

$$
P=\frac{f}{N} X 100 \%
$$

$\mathrm{P}=$ Persentase

$\mathrm{F}=$ Frekunsi

$\mathrm{N}=$ Jumlah Responden

$100 \%=$ Bilangan Tetap

Dengan demikian akan diketahui persepsi petani bawang merah terhadap program pengembangan tanaman bawang merah dengan persentase yang ada.

\section{HASIL DAN PEMBAHASAN}

Persepsi petani terhadap program pengembangan bawang merah di Kabupaten Kampar sangat diperlukan, karena petani merupakan objek pelaksana program yang telah dirancang oleh pemerintah, didasarkan pada fakta lapangan dari petani bawang merah di Kabupaten Kampar saat ini dilakukan analisis persepsi petani dengan pendekatan pembobotan dan skoring. Adapun prinsip penetapan bobot terhadap kriteria yang dipilih disesuaikan dengan tingkat 
penilaian petani terhadap pelaksanaan program pengembangan bawang merah. Demikian juga klasifikasi skoring yang dibedakan sebagai berikut: tidak baik (1), kurang baik (2), baik (3) dan sangat baik (4).

Berdasarkan hasil antara bobot masing-masing kriteria dengan nilai skornya, selanjutnya dilakukan penilaian terhadap persepsi petani bawang merah terhadap kinerja pemerintah khususnya program pengembangan bawang merah. Persepsi petani dikatakan tinggi jika persentase rataan nilai lebih dari 100, dikatakan sedang jika persentase rataan sama dengan 100, dikatakan rendah jika persentase rataan kurang dari 100. Hasil nya dapat dilihat pada tabel berikut ini:

Tabel 1. Bobot Tingkat Persepsi Petani Bawang Merah terhadap Program Pengembangan Bawang Merah di Kabupaten Kampar.

\begin{tabular}{|c|c|c|c|c|c|c|c|c|c|}
\hline Kriteria & $\begin{array}{c}\text { Kejelasan } \\
\text { Program }\end{array}$ & $\begin{array}{c}\text { Ketepatan } \\
\text { sasaran } \\
\text { program }\end{array}$ & $\begin{array}{l}\text { Dukungan/ } \\
\text { keterlibatan } \\
\text { masyarakat }\end{array}$ & $\begin{array}{c}\text { Pendamping } \\
\text { An \& } \\
\text { Penyuluhan }\end{array}$ & $\begin{array}{l}\text { Bantuan } \\
\text { Saprodi }\end{array}$ & $\begin{array}{c}\text { Bantuan } \\
\text { Pembiayaan }\end{array}$ & $\begin{array}{c}\text { Bantuan } \\
\text { Bibit }\end{array}$ & Total & Bobot \\
\hline 1 & 5 & 12 & 0 & 0 & 0 & 0 & 0 & 17 & 0.02 \\
\hline $\begin{array}{l}\text { (tidak } \\
\text { baik) }\end{array}$ & & & & & & & & & \\
\hline 2 & 12 & 20 & 0 & 0 & 0 & 0 & 18 & 50 & 0.07 \\
\hline $\begin{array}{c}\text { (kurang } \\
\text { baik) }\end{array}$ & & & & & & & & & \\
\hline $\begin{array}{c}3 \\
\text { (baik) }\end{array}$ & 52 & 67 & 72 & 13 & 92 & 23 & 69 & 388 & 0.55 \\
\hline $\begin{array}{c}4 \\
\text { (sangat } \\
\text { baik) }\end{array}$ & 31 & 1 & 28 & 87 & 8 & 77 & 13 & 245 & 0.35 \\
\hline Total & 100 & 100 & 100 & 100 & 100 & 100 & 100 & 700 & 0.99 \\
\hline
\end{tabular}

\section{2.}

Setelah didapat bobot masing-masing kriteria kemudian dilakukan scoring untuk tiap kriteria sebagai berikut:

Tabel 2. Persentase Kriteria Persepsi Petani bawang Merah terhadap Program Pengembangan Bawang Merah di Kabupaten Kampar.

\begin{tabular}{|c|c|c|c|}
\hline No. & Kriteria (persepsi terhadap) & Bobot x Score & Persentase \\
\hline 1. & Kejelasan Program & 40.37 & 93.27 \\
\hline 2. & Ketepatan sasaran program & 38.84 & 89.74 \\
\hline 3. & Dukungan/keterlibatan masyarakat & 49.40 & 114.10 \\
\hline 4. & Pendampingan \& penyuluhan & 37.60 & 86.81 \\
\hline 5. & Bantuan Saprodi & 53.40 & 123.47 \\
\hline 6. & Bantuan Pembiayaan & 39.60 & 91.49 \\
\hline \multirow[t]{3}{*}{7.} & Bantuan Bibit & 43.76 & 101.10 \\
\hline & Total Bobot x Score & 302,97 & 700 \\
\hline & Rataan & 43.28 & 100 \\
\hline
\end{tabular}

Dari tabel 2 diatas dapat dilihat bahwa persepsi petani yang masuk pada kategori tinggi adalah kriteria dukungan/keterlibatan masyarakat sebesar $114,10 \%$, kriteria bantuan saprodi sebesar $123.47 \%$, dan bantuan bibit sebesar 
$101.10 \%$ artinya rataan persepsi petani bawang merah di Kabupaten Kampar dengan kriteria tersebut lebih dari 100\%. Kemudian kriteria persepsi petani yang masuk dalam kategori rendah adalah kejelasan program sebesar 93,27\%, ketepatan sasaran program sebesar $89,74 \%$, pendampingan dan penyuluhan sebesar $86.81 \%$ dan bantuan pembiayaan sebesar 91,49\%, kriteria ini dikatakan rendah karena persentase rataan kriteria tersebut kurang dari $100 \%$.

Dapat dijelaskan bahwa persepsi petani kriteria dukungan/keterlibatan masyarakat termasuk kategori tinggi karena memang pemerintah Kabupaten Kampar dari awal sudah melibatkan masyarakat setempat untuk dapat menjadi bagian dari program pengembangan bawang merah. Karena program ini benarbenar dirintis dari awal mengingat bahwa masyarakat petani di Kabupaten Kampar belum terbiasa berbudidaya tanaman bawang merah. Dari hasil penelitian Amalia dkk (2016) didekripsikan bahwa pemerintah Kabupaten Kampar mendatangkan petani bawang merah dari Berebes kemudian diberikan lahan sebagai pilot project seluas $13 \mathrm{Ha}$ di Desa Sungai Geringging, sehingga petani setempat dapat melihat langsung bagaimana berbudidaya tanaman bawang merah, selain itu Pemerintah Kabupaten Kampar juga menjamin pasar untuk tanaman bawang merah diKabupaten Kampar. Setelah petani setempat melihat langsung selanjutnya Pemerintah Kabupaten Kampar merancang dan melaksanakan program pengembangan bawang merah dengan melibatkan kelompok tani di Kabupaten Kampar.

Selain itu bantuan saprodi dan bantuan bibit juga termasuk kategori tinggi artinya persepsi petani terhadap kriteria tersebut baik. Pemerintah Kabupaten Kampar dalam menyusun anggaran pengembangan bawang merah memang sangat memperhatikan saprodi dan benih. Karena program ini adalah program rintisan dimana perlu aplikasi teknologi yang tepat untuk mengatasi kondisi lahan di Kabupaten Kampar yang pada umunya adalah lahan gambut yang berbeda dengan lahan di Berebes yang merupakan lahan subur. Dalam pelaksanaannya pemerintah memberikan bantuan saprodi seperti kapur dolomit untuk mengatasi lahan asam, terpal, dan pompa air. Kemudian bantuan bibit juga masuk dalam kategori tinggi karena memang bibit bawang merah disediakan oleh pemerintah dan petani sangat terbantu karena kebutuhan bibit bawang merah per hektar cukup besar yaitu $1.200 \mathrm{~kg}$ dengan harga Rp.45.000,-/kg. Apabila bibit bawang merah 
tidak dibantu oleh pemerintah maka petani akan sangat berat, sehingga pada pelaksanaan program ini pemerintah memberikan bantuan benih untuk tiap kelompok tani yang ikut dalam program ini.

Untuk kriteria kategori rendah yaitu kejelasan program, ketepatan sasaran program, pendampingan dan penyuluhan, dan bantuan pembiayaan dapat dijelaskan bahwa persepsi petani masih kurang baik untuk kriteria tersebut. Masih kurangnya sosialisasi dan perlunya pendampingan dan penyuluhan yang lebih intens mengingat program ini masih baru dirintis di Kabupaten Kampar. Selain itu persepsi petani terhadap bantuan biaya juga dirasakan masih kurang karena pengembangan program ini memerlukan teknologi yang tepat sesuai dengan kondisi di Kabupaten Kampar. Mengingat modal yang besar dari mulai pengolahan lahan, penanaman dan perawatan yang intens maka petani mempunyai persepsi bahwa bantuan biaya masih harus ditingkatkan.

\section{KESIMPULAN}

Persepsi petani terhadap Program Pengembangan Bawang Merah adalah yang masuk pada kategori tinggi adalah kriteria Dukungan/keterlibatan masyarakat sebesar $114,10 \%$, kriteria bantuan saprodi sebesar $123.47 \%$, dan bantuan bibit sebesar $101.10 \%$ artinya rataan persepsi petani bawang merah di Kabupaten Kampar dengan kriteria tersebut lebih dari 100\%. Kemudian kriteria persepsi petani yang masuk dalam kategori rendah adalah kejelasan program sebesar 93,27\%, ketepatan sasaran program sebesar 89,74\%, pendampingan dan penyuluhan sebesar $86.81 \%$ dan bantuan pembiayaan sebesar $91,49 \%$, kriteria ini dikatakan rendah karena persentase rataan kriteria tersebut kurang dari $100 \%$.

\section{SARAN}

1. Pemerintah perlu meningkatkan sosialisasi program, pendampingan dan penyuluhan untuk induksi teknologi agar program ini dapat berhasil dan berkelanjutan.

2. Perlu peningkatan pembiayaan permodalan bagi petani bawang merah mengingat besarnya modal yang dibutuhkan dalam budi daya tanaman bawang merah di Kabupaten Kampar.

\section{DAFTAR PUSTAKA}

Agresti,A. 2002. Categorical Data Analysis. Wiley Interscience. New York. 
Amalia, Hamdan Yasid dan Asgami Putri. 2015. Analisis Komoditi Unggulan Bawang Merah di Kecamatan Kampar Kiri Kabupaten Kampar. Jurnal Ilmiah Pertanian Vo. 10 No.2 Agustus 2015. Pekanbaru

Badan Litbang Pertanian. 2006. Prospek dan Arah Pengembangan Agribisnis Bawang Merah. http://www.litbang.deptan.go.id/special/publikasi.

BPTP Sultra (Balai Pengkajian Teknologi Pertanian Sulawesi Tenggara). 2009. Teknologi Budidaya Bawang Merah di Lahan Kering. http://sultra.litbang.deptan.go.id.

BPTP Jatim (Balai Pengkajian Teknologi Pertanian Jawa Timur). 2012. Analisis Keberlanjutan Usaha Bawang Merah di Kabupaten Nganjuk Jawa Timur. http://jatim.litbag.deptan.go.id.

Ditjen PHP (Direktorat Jendral Pengolahan dan Pemasaran Hasil Pertanian). 2006. Road Map Pascapanen, Pengolahan dan Pemasaran Hasil Bawang Merah. http://agribisnis.deptan.go.id.

Ginting, H. 2002. Pengaruh Daya Serap Teknologi Pterhadap Usaha Tani yang dilakukan oleh Petani. Laporan Hasil Peneltian Universitas Sumatra Utara Fakultas Pertanian.

Hanafi, Rita. 2010. Pengantar Ekonomi Pertanian. Penerbit Andi Yogyakarta. Yogyakarta.

Iriani, E. 2013. Prospek Pengembangan Inovasi Teknologi Bawang Merah di Lahan Optimal (Lahan Pasir) dalam Upaya Peningatan Pendapatan Petani. Jurnal Litbang Propinsi Jawa Tengah Vol.11 No.2 Desember 2013.

Koestoni, T. dan S.Sastrosiswojo. 1991. Pengaruh Waktu Tanam Bawang merah terhadap Dinamika Populasi Ulat Bawang di Dataran Rendah. Laporan Hasil Penelitian Hortikultura Lembang.

Purbiati, T. 2012. Potensi Pengembangan Bawang Merah di Lahan Gambut. Jurnal Litbang Pertanian Vol.13 No.3 September 2012.

Sayaka, B. Dan Y. Supriyatna. 2009. Kemitraan Pemasaran Bawang Merah di Kabupaten Brebes Jawa Tengah. http://pse.litbang.deptan.go.id

Sudjana. 2001. Metode Statistika, Edisi Revisi Cet 6. Bandung:Tarsito.

Suhardi. 1993. Pengaruh Watu Tanam dan Interval Penyemprotan Fungisida terhadap Intensitas Serangan Alternaria porii dan Collelotricum gloeosporioides pada Bawang Merah. Bull. Penel. Hort. 26 (I)

Siswandi. 2006. Budi Daya Tanaman Sayuran. Citra Aji Parama. Yogyakarta. 